\section{RMD Open}

Rheumatic \&

Musculoskeletal Diseases

\title{
Patient-physician collaboration in rheumatology: a necessity
}

\author{
Elena Nikiphorou, ${ }^{1,2}$ Alessia Alunno, ${ }^{3}$ Loreto Carmona, ${ }^{4}$ Marios Kouloumas, ${ }^{5}$ \\ Johannes Bijlsma, ${ }^{6}$ Maurizio Cutolo ${ }^{7}$
}

To cite: Nikiphorou E, Alunno A, Carmona L, et al. Patient-physician collaboration in rheumatology: a necessity. RMD Open 2017;3:e000499. doi:10.1136/ rmdopen-2017-000499

- Prepublication history for this paper is available online. To view these files please visit the journal online (http://dx.doi. org/10.1136/rmdopen-2017000499).

Received 16 May 2017 Revised 13 June 2017 Accepted 14 June 2017

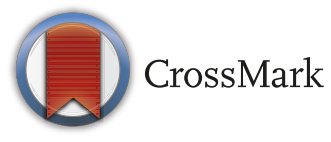

${ }^{1}$ Academic Rheumatology Department, King's College London, London, UK ${ }^{2}$ Rheumatology Department, Whittington Hospital NHS Trust, London, UK

${ }^{3}$ Department of Medicine, Rheumatology Unit,University of Perugia, Italy

${ }^{4}$ Instituto de Salud

Musculoesqueletica, Madrid, Spain

${ }^{5}$ Cyprus League Against Rheumatism, Aglantzia, Cyprus ${ }^{6}$ Department of Rheumatology and Clinical Immunology, University Medical Center, Utrecht, The Netherlands ${ }^{7}$ Division of Clinical Rheumatology,Department of Internal Medicine, University of Genoa, Genoa, Italy

Correspondence to Dr Elena Nikiphorou; enikiphorou@gmail.com

\section{ABSTRACT}

Over the past few decades, there has been significant and impressive progress in the understanding and management of rheumatic diseases. One of the key reasons for succeeding in making this progress has been the increasingly stronger partnership between physicians and patients, setting a milestone in patient care. In this viewpoint, we discuss the recent evolution of the physician-patient relationship over time in Europe, reflecting on the 'journey' from behind the clinic walls through to clinical and research collaborations at national and international level and the birth of healthcare professional and 'rheumatic' patient organisations. The role of expert patients and patient advocates in clinical and scientific committees now represents a core part of the decision-making process. In more recent years and following the recognition that the young patients, physicians and academics have a voice and needs of their own, including the need to be educated and instructed, has encouraged the establishment of youth organisations, enabling change and innovation to take place at a uniquely different level.

Rheumatology has witnessed rapid advances over time; from more than 100 years back when aspirin was 'the' treatment, through to the mid-20th century when the effects of cortisone were first observed, to current times, where biological agents and small molecules are catching headlines in the news. But would such progress have been made without interested clinicians and researchers dedicating their lives to understanding mechanistic pathways and therapeutic targets? More importantly, would this have been achieved without determined patients who believed, trusted and accepted treatments given to them? The answer is probably no. Scientific intelligence and the increasingly stronger partnership between physicians and patients over time have undoubtedly played a crucial role in better understanding rheumatic and musculoskeletal diseases (RMDs) and their treatment. The congregation of physicians, on the one hand, and patients, on the other, working together in partnership as a single unit rather than as different entities, has set important milestones and allowed the specialty to progress to a different level.

\section{PATIENTS AND PHYSICIANS WORKING IN PARTNERSHIP}

The relationship between patients and physicians has received attention since the Hippocratic times. ${ }^{1}$ It is undoubtedly a relationship that has changed and matured through the years, with almost a complete turnaround of role and attitude: the emphasis is now on the patient talking and the physician listening and understanding the needs of the patient; the physician giving opinion and information and the patient making choice together with the physician; the patient asking and the physician answering. The communication between physicians and patients in the majority of the communities has progressively evolved into an open dialogue, transforming patients from passive recipients of information and instructions to active participants in the management of their disease. The shift towards more patient-centred healthcare has necessitated important changes in the infrastructure and the way healthcare is delivered. This is, not surprisingly, more suited and more appealing to our target population of patients with chronic, rheumatic musculoskeletal diseases (RMDs) often in the setting of many other coexisting (comorbid) conditions. Interestingly in the most recent treatment guidelines for RMDs released by the European League Against Rheumatism (EULAR), one of the overarching principles is that treatment should be based on a shared-decision process between the patient and the physician. ${ }^{23}$ Patient empowerment through tailored education and information becomes therefore a crucial aspect of healthcare, which we strongly advocate. However, we recognise that although clinicians and health professionals are advised to educate patients and support them with information about their disease, they have limited 
guidance about how to do this and to communicate the evidence-based medicine in a way patients will understand. In this aspect, and in close collaboration between physicians and patients, the EULAR set of recommendations for education of patients with inflammatory arthritis $^{4}$ are well-received, as are recent discussions focusing on translating all recommendations in a friendly patient language. We should not forget that communication between patients and doctors is critical not just in clinical practice, but also in clinical research. In fact, the two are deeply linked as one informs the other, especially as there is evidence that the patient and physician perspectives diverge. For instance, in the development of the Rheumatoid Arthritis Impact of Disease (RAID) index, patients considered that 'coping' needed to be taken into account and doctors were not so in favour of this. The psychometric properties of the RAID, which includes 'coping', are better than other doctor-derived indices more widely used, for example, the 28-joint count Disease Activity Score (DAS28). ${ }^{5}$ Some groups even consider that probably the best strategy to achieve a comprehensive and valid definition of states in disease will be to concur in the same group of people experiences and technical expertise, that is, recruiting doctors with RMDs to 'translate' the experience to doctors. ${ }^{6}$

Outcomes Measures in Rheumatology (OMERACT) is a forum in which patient-researcher relationship is incredibly enriching (https://www.omeract.org/ patient_research_partners.php). OMERACT is an independent international think-tank and hands-on focused on outcome measures in rheumatology. The group, a mix of stakeholders, from doctors, researchers, agencies, industry and patients, meets every 2 years and works on agreed processes and projects between meetings. Recognising that nobody knows how arthritis changes one's life better than the people who have the condition, OMERACT has Patient Research Partners fully integrated into each stage of the OMERACT process. The majority of the most influential patient representatives in rheumatology have attended at least one OMERACT meeting. We recognise that patient research partners (PRPs) have made an important contribution to clinical research, helping define important outcome measures, such as minimum clinically important difference, recognising domains of concern, such as sleep and fatigue, and ensuring feasibility of assessments, such as in the tolerability of MRI scanning times. ${ }^{7}$

However, there is also the other side to the coin and it may be perceived that the call for patient involvement is perhaps going a little too far, with risks to becoming counterproductive. How much the patient perspective can and should be incorporated in clinical and scientific decisions can be subject to debate. As an example, the definition of treatment success for a clinician is often based purely on achieving a remission or at least low disease activity score, whereas for the patient remission may be completely unrelated or only partially related to a score reflecting disease activity. Instead, other important aspects of disease may be of greater relevance to the patient when it comes to whether treatment has succeeded or failed: for example, improved sleep, ability to remain socially engaged and in employment may be what disease remission and treatment success means to them. $^{8-13}$

We therefore observe with delight that regulatory authorities require the patient perspective to be taken into account. Aside from the inclusion of patient-reported outcomes in trials, the introduction of the patient's voice in the evaluation of medicines and the patient's contribution in the assessment of benefit and risk of therapeutic approaches is required. ${ }^{1415}$ Of all stakeholders, regulators are the ones most interested in patients being educated in the process of drug development and applaud and support initiatives such as the European Patients Academy (http://www.eupati.eu) and initiatives that focus on bringing the patient closer to the centre of medicines development, authorisation and reimbursement processes in the European Union (EU). Finally, we recognise that this evolution in the physicianpatient relationship has bridged many gaps between the two parties, prompting patient and physician groups to come together and work collaboratively towards achieving common goals, and strengthening research in rheumatology.

\section{THE BIRTH OF HEALTHCARE PROFESSIONAL/PHYSICIAN ORGANISATIONS}

The first attempt to establish a worldwide group for the study and control of rheumatic diseases dates back to 1913 but it sadly failed due to World War I intervening. In 1925 the International League Against Rheumatism (ILAR) was formed in Paris representing the first step towards the development of regional leagues, namely Pan-American League of Rheumatology Associations (PANLAR) in the Pan-American Region in 1943, EULAR in the European region in 1947, the Asia Pacific League of Associations for Rheumatology in 1963 and in 1989 the African League (AFLAR). At national level, the American Rheumatism Association was founded in 1925, in 1965 renamed the American College of Rheumatology.

A unique feature of EULAR is its three pillars (medical doctors/scientists, health professionals and people with RMDs) representing a broad audience and ensuring that voices from all relevant stakeholders are heard.

At present, we realise that at national level each country under the EULAR umbrella pursues similar objectives through their individual rheumatology societies. In the majority of cases, these represent highly active communities of rheumatology clinicians and academics with links to patient organisations and health professional associations working together in several clinical and research domains relating to the specialty.

What has been a real credit to patients with RMDs across the globe was the formation of organisations to support programmes in less developed countries that aim 


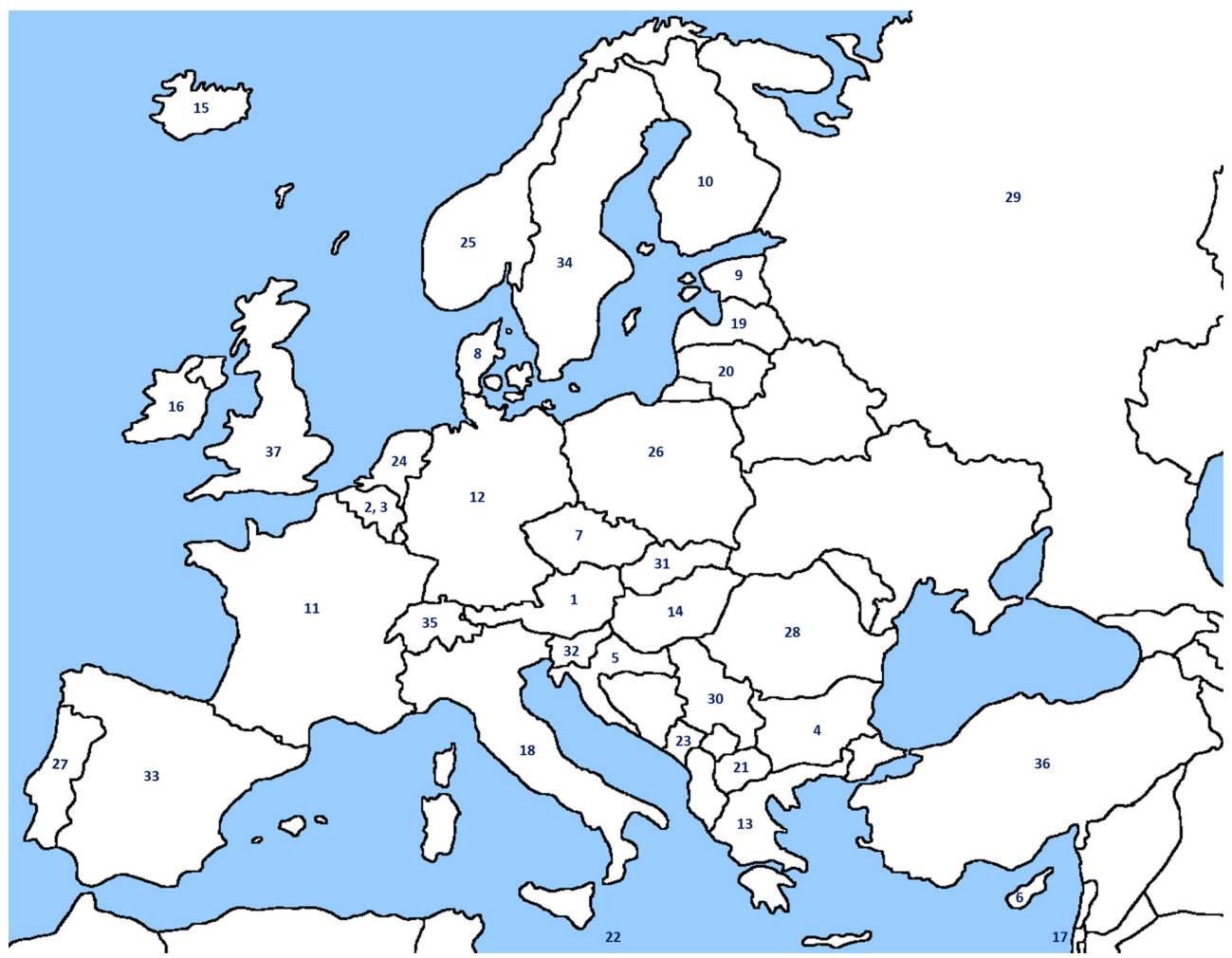

Figure 1 People with Arthritis and Rheumatism organisations across Europe.

to enhance the practice and education of rheumatology. For example, ILAR has a focused mission of advancing rheumatology in countries with an exceptional need. ILAR projects have varied in their focus from recommendations for treating rheumatic diseases to setting up specialist clinics in low-income, middle-income countries to web-based educational programmes aimed at patients with rheumatic disease.

\section{THE ROLE OF PATIENT ORGANISATIONS}

The crucial role of the patients as service users in identifying areas of improvement in healthcare provision as well as the growing need to engage patients in initiatives to improve on clinical and academic fronts has been prominent over the past decade. As a result, patient organisations were gradually established across countries, many of which have rightly gained key roles within executive committees of healthcare professionals (figure 1). This way it has been possible to have the patient's voice and perspective heard and taken into account. We enthusiastically support the pairing of patient and physician organisations as it inevitably helps identify key areas that need development and addressing for patients with RMDs (table 1).

Many national patient organisations produce newsletters, patient guidebooks and organise meetings and gatherings bringing people together. As a consequence of their many roles, it is evident that patient organisations also raise the awareness about the burden of RMDs as well as the impact to the patients and provide information, support and education to the patients to empower them to self-manage their disease. The majority of these organisations have their own website and are active on social media platforms such as Facebook and Twitter, reaching out to as many people as possible. Patient forums and online blogs are becoming more and more frequent and have provided platforms for people to openly communicate, build communities, share experiences, exchange information and learn from each other. Although there are mixed views about the use of social media in this manner, this seems to be the way the future of rheumatology is progressing and embracing this is probably better than resisting it.

Even in small communities/countries, patients have had a strong presence, working in partnership with rheumatologists at national and international level to enforce national strategic plans, but also raise awareness and contribute to improving the future of patients with RMDs globally. EULAR had a strong influence in encouraging patient collaboration with professionals in research, producing recommendations for inclusion of patient representatives in scientific projects. ${ }^{16}{ }^{17}$ PRPs are therefore highly recommended and are currently involved in all EULAR research initiatives.

The EULAR People with Arthritis and Rheumatism across Europe (PARE) standing committee (http:// www.eular.org/pare.cfm), set up in 2008 to succeed the EULAR Social Leagues, actively engages national organisations of people with RMDs across Europe-related initiatives focusing on improving quality of life in patients with these diseases. 
Table 1 People with Arthritis and Rheumatism across Europe organisations 2015/2016

\begin{tabular}{|c|c|c|c|c|c|}
\hline Map number & Acronym & Full name & Country & Year of foundation & $\begin{array}{l}\text { Members (2016 } \\
\text { update) }\end{array}$ \\
\hline 1 & & Österreichische Rheumaliga & Austria & 1995 & \\
\hline 2 & & Reumanet vzw. & Belgium (Flanders) & 2011 & 5000 \\
\hline 3 & CLAIR & $\begin{array}{l}\text { Confédération de Lutte contre } \\
\text { les Affections Inflammatoires } \\
\text { Rhumatismales }\end{array}$ & Belgium (Wallonia) & 2004 & 2500 \\
\hline 5 & HRVATSKA & Liga Protiv Reumatizma & Croatia & 1992 & 5500 \\
\hline 6 & CYPLAR & $\begin{array}{l}\text { Cyprus League Against } \\
\text { Rheumatism }\end{array}$ & Cyprus & 1984 & 4450 \\
\hline 10 & & Suomen Reumaliitto Ry & Finland & 1947 & 45000 \\
\hline 11 & AFLAR & $\begin{array}{l}\text { Association Française de } \\
\text { Lutte Anti-Rhumatismale }\end{array}$ & France & 1928 & 6500 \\
\hline 12 & & $\begin{array}{l}\text { Deutsche Rheuma-Liga } \\
\text { Bundesverband e.V. }\end{array}$ & Germany & 1970 & 280000 \\
\hline 13 & 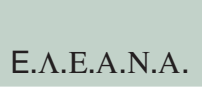 & $\begin{array}{l}\text { Hellenic League Against } \\
\text { Rheumatism }\end{array}$ & Greece & 1978 & \\
\hline 14 & & $\begin{array}{l}\text { Magyar Reumabetegek } \\
\text { Egyesülete }\end{array}$ & Hungary & 1998 & \\
\hline 15 & & Gigtarfélag Íslands & Iceland & 1976 & 5030 \\
\hline 20 & & Lietuvos Artrito Asociacija & Lithuania & 1998 & 2000 \\
\hline 21 & NORA & $\begin{array}{l}\text { Non-governmental } \\
\text { Organisation for Rheumatism } \\
\text { \& Arthritis }\end{array}$ & Macedonia & 2008 & 1009 \\
\hline 22 & Malta-ARAM & $\begin{array}{l}\text { Arthritis and Rheumatism } \\
\text { Association Malta }\end{array}$ & Malta & 2007 & 380 \\
\hline 23 & & $\begin{array}{l}\text { Association for Helping } \\
\text { Persons with Rheumatic } \\
\text { Diseases }\end{array}$ & Montenegro & 2003 & 2150 \\
\hline 24 & & $\begin{array}{l}\text { National Association } \\
\text { ReumaZorg Nederland }\end{array}$ & Netherlands & 2014 & \\
\hline 25 & NRF & Norsk Revmatikerforbund & Norway & 1951 & 34000 \\
\hline 26 & REF & $\begin{array}{l}\text { Ogolnopolska Federacja } \\
\text { Stowarzyszen Reumatykow }\end{array}$ & Poland & 2000 & \\
\hline 27 & LPCDR & $\begin{array}{l}\text { Liga Portuguesa Contra as } \\
\text { Doenças Reumáticas }\end{array}$ & Portugal & 1982 & 500 \\
\hline 28 & & $\begin{array}{l}\text { Liga Romana Contra } \\
\text { Reumatismului }\end{array}$ & Romania & 2002 & 650 \\
\hline
\end{tabular}


Table 1 Continued

\begin{tabular}{|c|c|c|c|c|c|}
\hline Map number & Acronym & Full name & Country & Year of foundation & $\begin{array}{l}\text { Members (2016 } \\
\text { update) }\end{array}$ \\
\hline 29 & N.A.D.E.G.D.A. & $\begin{array}{l}\text { National Public Organisation } \\
\text { of disabled people }\end{array}$ & Russia & 2006 & \\
\hline 30 & ORS & $\begin{array}{l}\text { The Association of Rheumatic } \\
\text { Diseases Patients of the } \\
\text { Republic of Serbia }\end{array}$ & Serbia & 2007 & 1400 \\
\hline 31 & & Liga proti reumatizmu & Slovakia & 1990 & \\
\hline 32 & DRS & $\begin{array}{l}\text { Slovenian Rheumatism } \\
\text { Association }\end{array}$ & Slovenia & 1983 & 1550 \\
\hline 33 & LIRE & Liga Reumatológica Española & Spain & 1973 & \\
\hline 34 & & Reumatikerförbundet & Sweden & 1945 & 50000 \\
\hline 35 & RLS & Rheumaliga Schweiz & Switzerland & 1958 & \\
\hline 36 & & Türkiye Romatizma Dernegi & Turkey & 1977 & \\
\hline 37 & ARMA & $\begin{array}{l}\text { Arthritis and Musculoskeletal } \\
\text { Alliance }\end{array}$ & UK & 1972 & \\
\hline
\end{tabular}

PARE is involved in a number of projects, aiming to develop strong networks of effective, user-led organisations of people with RMDs; to ensure the voice of people with RMDs is heard and has influence among decision makers within Europe; to create powerful alliances that will make a difference to the lives of these people and to raise the awareness for RMDs. ${ }^{18} 19$ Key PARE projects include the coordination of the World Arthritis Day (www.worldarthritisday.org) which aims to raise awareness of all forms of RMDs among the medical community, people with RMDs and the general public. Second, it organises the EULAR Annual European Conference of PARE which aims to inspire, educate and empower the National Patient Representatives. PARE has established a European Network of Patient Research Partners in order to influence research from a patient perspective and participation in EULAR scientific projects.

Other similar organisations to PARE include AGORA (http://www.agora-platform.eu), an 'umbrella platform' representing patient organisations of people with RMDs in Southern Europe. Set up in 2011, with a motto of 'Together we can', AGORA has been an inspirational community of patients working towards improving quality of life and building a better future for people with RMDs. Many patient organisations have just like PARE set up their own annual conferences with the primary goal of inspiring, motivating and educating patient representatives on RMDs.

The role of patient advocates has gained increasing attention over time, fostering partnerships not only between patients and their families/carers, but importantly also between healthcare professionals, bridging gaps in care and improving communication but also with policymakers in order to influence and to be involved in the health policy. PARE's vision for people with RMDs to be able to live full and independent lives has been a strong influence for patient advocates coming forward.
As a result, advocacy activities towards the EU have had an important influence by creating public and political interest in RMDs and in people suffering from these. Starting back in 2004 with a campaign called Alliance Against Arthritis and working together with all three pillars of EULAR (clinicians, heath professionals and patient representatives) PARE organises activities in Brussels yearly, aiming to engage the policymakers raising awareness for RMDs and stressing the need to implement effective policies and strategies to tackle the RMDs. This has led to two written declarations on RMDs (2005 and 2008) highlighting the importance of the EU and its Member States in recognising the socioeconomic importance and other consequences of RMDs across all ages and assigning them appropriate priority. The launch of the first Written Declaration in 2005, instigated by EULAR, was officially announced at a reception in the European Parliament in Strasbourg. Also an Interest group was established consisting of parliamentarians and meeting three times a year to discuss relevant issues to RMDs.

Furthermore, the Secretariat of the European Parliament Interest Group on RMDs (2009-2014) has been run by EULAR and EULAR participated in the Council Conclusions on 'Innovative approaches for chronic diseases in public health and healthcare systems' elaboration in 2010. As a consequence, the document released in 2013 acknowledged RMD burden and recognised that consistent efforts should be invested in research and innovation in this field. Of note, the legislative texts of Horizon 2020, the EU framework programme for research and innovation running from 2014 to 2020, included RMDs among the relevant chronic diseases that Horizon 2020 should address. With an 80 billion EUR budget, Horizon 2020 will provide resources to foster high-quality research in-among others-rheumatology and increase our knowledge on these conditions eventually improving their management. 
Finally, the European Commission has just launched (May 2017) the EU Network on Rare Diseases (ERN) with a branch to represent Rare Connective Tissue and Musculoskeletal Diseases (ERN ReCONNECT). The latter is endorsed by EULAR and PARE and has a mission to develop a framework for the delivery of high-quality, innovative, sustainable and equitable standard of care and practice for better access to care of European patients with rare Connective Tissue Diseases (rCTDs). All patient associations representing rCTDs have been involved in this initiative. The three main thematic groups of diseases identified in the ERN ReCONNET include rare autoimmune, complex autoimmune and rare hereditary connective tissue and musculoskeletal diseases (http:// rd-connect.eu/news/european-commission-approves-23european-reference-networks).

\section{MAKING THE VOICE OF THE YOUNG HEARD}

We supported in recent years the need to make the voice and perspective of young physicians and patients with RMDs heard at national and international level and this has finally led to the establishment of several youth groups. In 2009 the EMerging EULAR NETwork (EMEUNET; http://emeunet.eular.org) was established with the aim of bringing young aspiring rheumatologists and academics together to work towards enhancing the quality of their own education and to foster collaborations among emerging rheumatologists in EULAR countries. ${ }^{20}$ To date, EMEUNET is the largest European young rheumatologist group engaging in a number of educational initiatives, many linked with larger organisations including EULAR. At national level, several trainee networks exist, many rapidly growing in numbers and having an active influence on the way training is delivered in their respective countries. Examples include the British Rheumatologists in Training network and the Italian Young Rheumatologists Group .

Similarly, from the patients' side, the Young PARE group (http://www.youngpare.org), recently developed within EULAR PARE, has been working towards establishing and strengthening youth patient organisations in European countries. This move stemmed primarily from the appreciation that the needs and priorities of young compared with adult patients differ and recognising these needs and priorities is crucial in order to optimise the management and relationship of young people with physicians

\section{FUTURE PROSPECTS AND FINAL THOUGHTS}

So to answer the question of whether there is value in physician-patient collaboration, we conclude that there can really only be one answer: a simple, but strong and loud 'yes'. Such collaboration is undoubtedly necessary to reach the mutual goal of optimising patient care and clinical outcomes, education and self-management and we are delighted to see it happening at two levels: the young and the senior/more established groups.
The science and knowledge are necessary for moving forward in the medical world. However, the real source of strength and potential for change draws inspiration from our patients; many highly motivated and with unique personal attributes striving for quality in healthcare and supporting fellow patients and healthcare professionals. It is one thing recognising this, though, and another actively doing something about it. Undoubtedly 'expert' patients and patient advocates in clinical areas but also scientific committees to strengthen patient representation will remain central to the future of rheumatology.

New and provocative views centre on how the patient perspective could modulate the physician perspective. Physicians tend to think that they can easily overtake the patient rule in research and in decisions, 'we are all patients'.

In this regard, a final thought to learning environments could be a breeding ground for improving the patient-doctor relationship, and even more to normalise it. The EULAR School of Rheumatology ( eular.org $\rightarrow$ school_of_rheumatology.cfm) has established a specific task force and classroom with the aim of developing ideas on how to further involve the patient perspective in the teaching and learning of future professionals. This might even imply expert and trained patients teaching future young doctors and health professionals at university, making relations more balanced, letting aside paternalism and creating a more patient-centred atmosphere.

With these prospects, the future landscape of rheumatology in Europe is certainly changing and, we believe, on the right track for achieving this important mission: to keep to the lowest limit the global burden of RMDs.

Acknowledgements The authors thank Florian Klett for his help with acquiring information on PARE organisations across Europe.

Contributors EN conceived the idea for writing this manuscript and provided a first draft. EN and AA produced a second draft which was then critically reviewed by LC, MK, JB and MC and a revised draft produced by EN and AA. The final draft was approved by all co-authors.

Competing interests EN is Chair of the EMerging EULAR NETwork (EMEUNET) AA is Chair-Elect of the EMerging EULAR NETwork (EMEUNET). LC is Technical Secretary of the patient Spanish League against Rheumatism. MK is President of the Cyprus League Against Rheumatism \& Past Vice President of EULAR Representing PARE. JB is President of EULAR. MC is Former Chairman of ILAR.

Provenance and peer review Not commissioned; externally peer reviewed. Data sharing statement No additional data are available.

Open Access This is an Open Access article distributed in accordance with the Creative Commons Attribution Non Commercial (CC BY-NC 4.0) license, which permits others to distribute, remix, adapt, build upon this work non-commercially, and license their derivative works on different terms, provided the original work is properly cited and the use is non-commercial. See: http://creativecommons.org/ licenses/by-nc/4.0/

(C) Article author(s) (or their employer(s) unless otherwise stated in the text of the article) 2017. All rights reserved. No commercial use is permitted unless otherwise expressly granted.

\section{REFERENCES}

1. Dorr Goold S, Lipkin M. The doctor-patient relationship: challenges, opportunities, and strategies. J Gen Intern Med 1999;14 Suppl 1:S26-33.

2. Strehl C, Bijlsma JW, de Wit M, et al. Defining conditions where longterm glucocorticoid treatment has an acceptably low level of harm 
to facilitate implementation of existing recommendations: viewpoints from an EULAR task force. Ann Rheum Dis 2016;75:952-7 http://ard. bmj.com/lookup/doi/.

3. Smolen JS, Landewé R, Breedveld FC, et al. EULAR recommendations for the management of rheumatoid arthritis with synthetic and biological disease-modifying antirheumatic drugs. Ann Rheum Dis 2017;0:1-18.

4. Combe B, Landewe R, Daien Cl, et al. 2016 update of the EULAR recommendations for the management of early arthritis. Ann Rheum Dis 2017;76:948-59 http://ard.bmj.com/lookup/doi/.

5. Zangi HA, Ndosi M, Adams J, et al. European League Against Rheumatism (EULAR). EULAR recommendations for patient education for people with inflammatory arthritis. Ann Rheum Dis 2015;74:954-62.

6. Gossec L, Paternotte S, Aanerud GJ, et al. Finalisation and validation of the rheumatoid arthritis impact of disease score, a patient-derived composite measure of impact of rheumatoid arthritis: a EULAR initiative. Ann Rheum Dis 2011;70:935-42 http://www.ncbi. nlm.nih.gov/pubmed/21540201.

7. Acebes C, Andreu JL, Balsa A, et al. Exploring the remission concept in rheumatoid arthritis with patients and rheumatologists: time for a new approach? Clin Exp Rheumatol 2017

8. de Wit M, Kirwan JR, Tugwell P, et al. Successful Stepwise Development of Patient Research Partnership: 14 Years' Experience of Actions and Consequences in Outcome Measures in Rheumatology (OMERACT). Patient 2017;10:141-52 http://link. springer.com/.

9. de Wit MP, Koelewijn-van Loon MS, Collins S, et al. "If i wasn't this robust": patients' expectations and experiences at the Outcome Measures in Rheumatology Conference 2010. Patient 2013;6:179-87.

10. Ferreira RJO, Duarte C, Ndosi M, et al. Suppressing inflammation in rheumatoid arthritis: Does patient global assessment blur the target? A practice-based call for a paradigm change. Arthritis Care Res 2017 http://doi.wiley.com/ (cited 2017 May 29).

11. Desthieux C, Granger B, Balanescu AR, et al. Determinants of patient-physician discordance in global assessment in psoriatic arthritis: a multicenter European study. Arthritis Care Res 2016 http://www.ncbi.nlm.nih.gov/pubmed/27998026 (cited 2017 May 29).

12. Nikiphorou $\mathrm{E}$, Radner $\mathrm{H}$, Chatzidionysiou $\mathrm{K}$, et al. Patient global assessment in measuring disease activity in rheumatoid arthritis: a review of the literature. Arthritis Res Ther 2016;18:251 http://www. ncbi.nlm.nih.gov/pubmed/27793211.

13. Heiberg T, Kvien TK. Preferences for improved health examined in 1,024 patients with rheumatoid arthritis: pain has highest priority. Arthritis Rheum 2002;47:391-7 http://doi.wiley.com/.

14. The patient's voice in the evaluation of medicines. EMA/607864/2013 http://www.ema.europa.eu/docs/en GB/ document_library/Report/2013/10/WC500153276.pdf.

15. Patient perspectives in medicines lifecycle. https://ec.europa.eu/ research/participants/portal/desktop/en/opportunities/h2020/topics/ imi2-2016-10-07.html.

16. de Wit MP, Berlo SE, Aanerud GJ, et al. European League Against Rheumatism recommendations for the inclusion of patient representatives in scientific projects. Ann Rheum Dis 2011;70:722-6.

17. Kirwan JR, de Wit M, Frank L, et al. Emerging Guidelines for Patient Engagement in Research. Value Health 2017;20:481-6 http://www. ncbi.nlm.nih.gov/pubmed/28292494.

18. de Wit MP, Kvien TK, Gossec L. Patient participation as an integral part of patient-reported outcomes development ensures the representation of the patient voice: a case study from the field of rheumatology. RMD Open 2015;1:e000129 http://rmdopen.bmj.com/ lookup/doi/.

19. van Dongen Jer?me Jean Jacques, de Wit $\mathrm{M}$, Smeets $\mathrm{HWH}$, et al ?They Are Talking About Me, but Not with Me?: A Focus Group Study to Explore the Patient Perspective on Interprofessional Team Meetings in Primary Care. The Patient - Patient-Centered Outcomes Research 2017;35 http://www.ncbi.nlm.nih.gov/ pubmed/28110379.

20. Jani M, Nikiphorou E, Croft AP, et al. Building the future of rheumatology: the role of national and international networks. Rheumatology 2017 http://www.ncbi.nlm.nih.gov/pubmed/ 28339820. 